\title{
Qualitative and Quantitative Characteristics of Sensi-1 Agrinak Chicken
}

\author{
Hasnelly, Iskandar S, Sartika T \\ Indonesian Research Institute for Animal Production, PO Box 221, Ciawi, Bogor \\ E-mail: nelly_zainal@yahoo.com
}

(received 05-04-2017; revised 14-06-2017; accepted 20-06-2017)

\begin{abstract}
ABSTRAK
Hasnelly, Iskandar S, Sartika T. 2017. Karakteristik kualitatif dan kuantitatif ayam SenSi-1 Agrinak. JITV 22(2): 68-79. DOI: http://dx.doi.org/10.14334/jitv.v22i2.1605

Salah satu galur ayam lokal pedaging yang dihasilkan Balai Penelitian Ternak (Balitnak) adalah Ayam Lokal SenSi-1 Agrinak. Galur baru ayam pedaging lokal ini telah dilepas dengan Surat Keputusan Menteri Pertanian No. 39/Kpts/PK.020/1/2017 pada tanggal 20 Januari 2017. SenSi-1 Agrinak diseleksi dari rumpun ayam lokal Sentul yang berasal dari Kabupaten Ciamis Jawa Barat. Kriteria seleksi berupa warna bulu abu polos, warna bulu pucak (putih bercak hitam) yang diaplikasikan terhadap jantan dan betinanya. Kriteria seleksi lain berupa jengger kacang (pea) dan bobot tubuh tertinggi $25 \%$ dari populasi per generasi ayam-ayam jantannya. Seleksi berlangsung selama enam generasi pada kondisi pemeliharaan intensif dengan ransum tunggal berkadar sekitar $17 \%$ protein kasar dan $2850 \mathrm{kkal} \mathrm{ME} / \mathrm{kg}$; kadar gizi lainnya mengikuti kadar yang disarankan untuk ayam ras White Leghorn. Pengukuran karakteristik kualitatif dan kuantitatif dilakukan pada sebanyak 499 ekor jantan dan 492 ekor betina SenSi-1 Agrinak Abu dan sebanyak 497 ekor jantan dan 492 ekor betina SenSi-1 Agrinak Pucak berumur 10-12 minggu dan 12 bulan. Hasil penelitian menunjukkan bahwa pada SenSi-1 Agrinak Abu, sebaran warna bulu abu pada jantan 55,51\%, betina 60,77\%; sebaran warna shank kuning jantan 52,51\%, betina 33,33\%; bentuk jengger kacang (pea) jantan $90.98 \%$, betina 89,23\%. Pada SenSi-1 Agrinak Pucak, sebaran warna bulu pucak jantan 75,65\%, betina 83,30\%; sebaran warna shank kuning jantan 51,91\%, betina 36,59\%; sebaran jengger kacang jantan 91,55\%, betina 92,28\%. Rataan bobot badan SenSi-1 Agrinak berbulu Pucak Jantan 908,76+ 130,98 g/ekor betina 750,53+ 110,56 g/ekor. Rataan Bobot bobot badan SenSi1 Agrinak berbulu Abu Jantan 886,38+142,93 g/ekor betina 739,17+ 118,87 g/ekor. Rataan bobot badan jantan terseleksi SenSi-1 Agrinak berbulu Pucak mencapai 1051+76g/ekor dan SenSi-1 Agrinak berbulu Abu 1015+107 g/ekor. Hasil penelitian ini dapat dijadikan sebagai dasar standarisasi ayam SenSi-1 Agrinak (Abu dan Pucak) sebagai male line ayam lokal pedaging.
\end{abstract}

Kata Kunci: Karakter, Sensi-1 Agrinak, Kualitatif, Kuantitatif

\section{ABSTRACT}

Hasnelly, Iskandar S, Sartika T. 2017. Qualitative and quantitative characteristics of SenSi-1 Agrinak chicken. JITV 22(2): 6879. DOI: http://dx.doi.org/10.14334/jitv.v22i2.1605

One of local chicken breeds develop in Indonesian Research Institute for Animal Production (IRIAP) is local SenSi-1 Agrinak chicken. This new improved local-meat-type breed was released with Ministry Agriculture Decree Number 39/Kpts/PK.020/1/2017 on $20^{\text {th }}$ January 2017. SenSi-1 Agrinak was originally selected from native Sentul chicken breed obtained from Ciamis district in West Java Province. Selection criteria were two feather colors of grey or black spotted white (pucak), which were applied to both males and females. Pea-comb type was also one criterion for males, applied at the age of 10 weeks. Live weight at the age of 10 weeks with the selection intensity of $25 \%$ was applied to each generation of males chicken. Selection proceeded for six generations. Selection program was carried out under standard feed formulae containing around $17 \%$ crude protein with $2850 \mathrm{kcal} \mathrm{ME} / \mathrm{kg}$, and containing other nutrients following the ones recommended for modern chicken of White Leghorn. Observation was conducted on each of about 2000 young chickens of grey and of Pucak SenSi-1 Agrinak both males and females age of 10 and 84 weeks. Results showed that grey SenSi-1 Agrinak chicken in total population, had: i) Grey feather color distribution of $55.51 \%$ in males, and $60.77 \%$ in females; ii) Yellow shank color of $52.51 \%$ in males, and $33.33 \%$ in females; iii) Pea type comb of $90.98 \%$ in males, and $89.23 \%$ in females; iv). Ten weeks live weight of $886.38+142.93 \mathrm{~g} / \mathrm{bird}$ in males, and 739.17+ 118.87 in females. Pucak SenSi-1 Agrinak chicken in total population, had: i) Pucak feather color of $75.65 \%$ in males, and $8330 \%$ in females; ii) Yellow shank color of $51.91 \%$ in males, and $36.59 \%$ in females; iii) Pea type comb of $91.55 \%$ in males, and $92.28 \%$ in females; iv) Ten weeks live weight of $908.76+130.98 \mathrm{~g} / \mathrm{bird}$ in males, and $750.53+110.56$ g/bird in females. Whilst for grey SenSi-1 Agrinak male chicken after selection had live weight at 10 weeks old of $1015+107$ g/bird, and for Pucak SenSi-1 Agrinak male chicken was 1051+76 g/bird. This initial performance information for those two breeds of considerably improved local chicken can be used as the base of information for SenSi-1 Agrinak breed for male line of meat type of local chicken breeding.

Key Words: Qualitative Character, Quantitative Character, SenSi-1 Agrinak Chicken 


\section{INTRODUCTION}

Indonesian native chicken apparently have species physical characteristic are grouped into at least 34 breeds or distinct groups of local chicken namely: Ayunai, Balenggek, Banten, Bangkok, Burgo, Bekisar, Cangehgar, Cemani, Ciparage, Gaok, Jepun, Kampung, Kasintu, Kedu (Black and White Kedu), Pelung, Lamba, Maleo, Melayu, Merawang, Nagrak, Nunukan, Nusa Penida, Olagan, Rintit or Walik, Sedayu, Sentul, Siem, Sumatera, Tolaki, Tukung, Wareng, Sabu, and Semau. Some of them are used for non-food purposes such as offerings for religious rituals, beauty - voice and feathers, and cock - fighting and indeed Kampung chickens are the most popular and kept almost throughout the entire country (Henuk \& Bailey 2014). Among them, 18 breeds are most popular in Indonesia while 11 breeds are good meat and eggs producers (Agriflo 2013; Han 2014).

Sentul chicken is an Indonesian native genetic source from Ciamis District, Province of West Java. The chicken has high growth performance and egg production (dual-purpose) and unique phenotypic uniformity compared to another original and local chickens.

The Indonesian Research Institute for Animal Production (IRIAP) has created broiler native chicken through selection of the Sentul chicken since 2010. In 2016, the SenSi-1 Agrinak $6^{\text {th }}$ generation chicken has produced superior breeding stock for male line of native chicken called SenSi-1 Agrinak through Decree of Minister of Agriculture of Indonesia Number 39/Kpts/PK.020/1/2017 on 20 January 2017. In the selection process, the chickens were divided into 2 groups based on their feather color: uniform grey color from the light gray to the dark grey and the Pucak feather (white feather with black spots by about 10$20 \%)$.

For the commercial scale, standardized qualitative and quantitative properties of the SenSi-1 Agrinak chicken are required. This study was conducted establish a baseline data on the characteristics of the SenSi-1 Agrinak chicken that may be used as a standard of the Sensi-1 Agrinak chicken.

\section{MATERIALS AND METHODS}

Released SenSi-1 Agrinak chicken in the 6th generation was sorted by their feather color:

1. SenSi-1 Agrinak with gray feather (499 heads male and 492 heads female)

2. SenSi-1 Agrinak with Pucak feather (497 heads male and 492 heads female)

The determination qualitative characteristic was based on the criteria described by Kusuma (2002) and Mansjoer (1981). Qualitative characteristics observed were the color of feather, the color of shank and shape of comb at the age of 10 weeks.

The body weight at 0-9 weeks was observed through the weighing $10 \%$ of the population every month. For the purpose of selection to the market demand (700$1000 \mathrm{~g} / \mathrm{head}$ ), individual weighing weight was conducted at the tenth week.

The quantitative characteristics (body size) observed were: adult body weight, length of beak, width of beak, length of head, width of head, length of neck, length of back, chest circumference, length of chest, length of upper thighs, length of lower thighs, length of shank of 12 months old hens.

The data of qualitative characteristics were analyzed using relative phenotypic frequency formula (percentage), while the data of quantitative characteristics were analyzed by simple descriptive statistics (average, maximum, minimum, standard deviation, coefficient of variant).

\section{RESULTS AND DISCUSSION}

\section{Qualitative characteristics}

Qualitative characteristics are crucial for the breeders as a trademark, so it is often considered in a breeding program. Those characteristics are controlled by one or more gens and slightly or not at all influenced by environment factor (Hardjosubroto 2002). Sidadolog (2011) suggested that qualitative characteristics such as the color of feather, type of comb and color of the shank are determined by one or more pair of major gen and will be inherited to its offspring. The qualitative inheritance always follows Mendel's law. Proportion variance was determined by the number of gen pairs and gen properties (dominant, intermediary, recessive, hypostatic epistasis, interaction) forming that property. Qualitative characteristics are unique traits used as a standard in dividing livestock animal type. The qualitative characteristics observed of the SenSi-1 chicken Agrinak in this study as male line of broiler chicken were the color of feather, type of comb and color of the shank.

\section{Color of the feather}

The color of feather of chicken is formed by pigment, physical structure or the combination of both (Natawiharja 2003). Colored feather is formed by gen (i), while the white feather of bird other than formed by inhibiting genes (I) toward the color pigment, is also formed by the absence of color pigmentation and does not have color gen (c) such as the albino chicken with white feather which is recessive to the colored feather gen (Hutt 1949). 
Male Grey SenSi-1 Agrinak Chicken

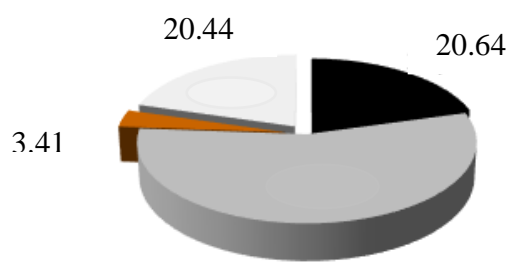

55.51
Fenale Grey SenSi-1 Agrinak Chicken

4.67

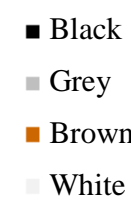

19.31

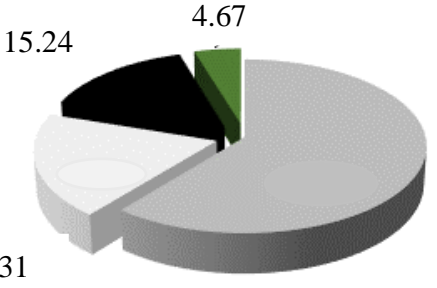

60.77 $\llbracket$ Grey

White

- Black

- Brown

Figure 1. Color distribution of feather of male and female Grey SenSi-1 Agrinak chicken (\%).
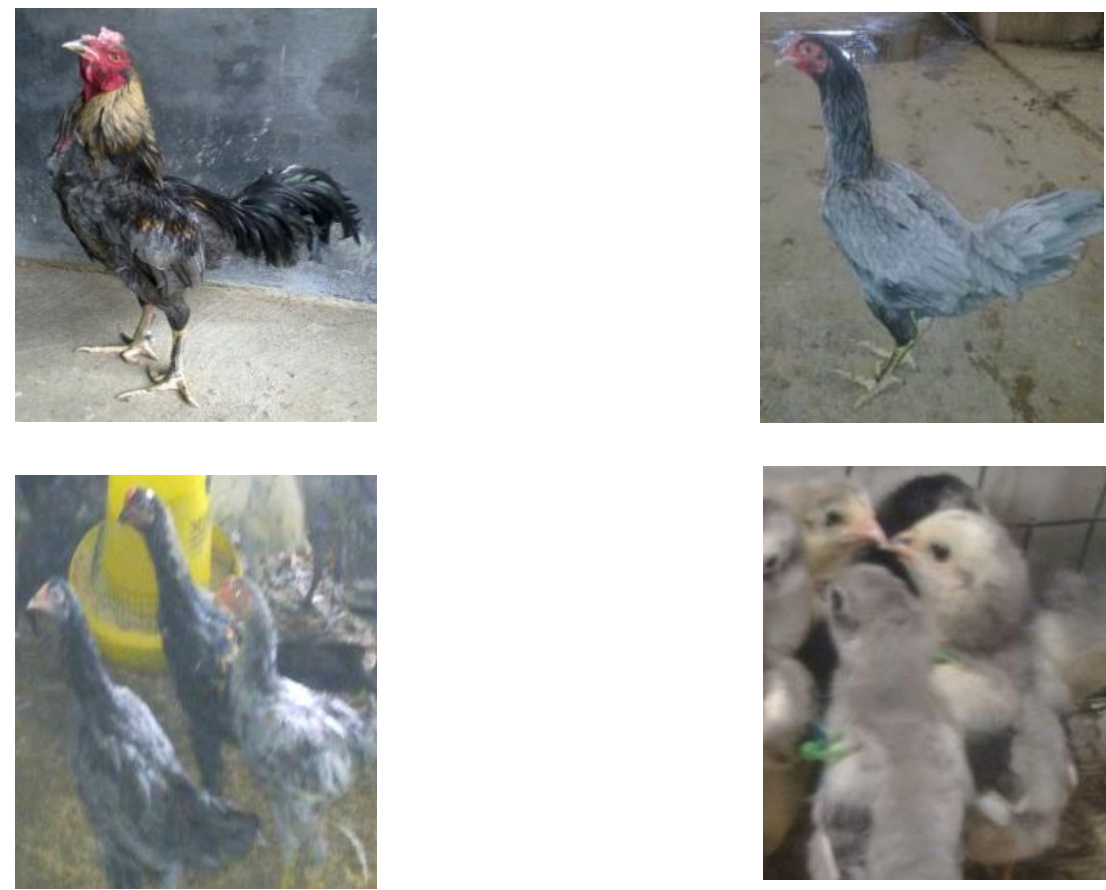

Figure 2. Grey SenSi-1 Agrinak chicken

The selected SenSi-1 Agrinak chickens were divided into two groups based on the color of feather: grey feather as Grey SenSi-1 Agrinak chicken and the white feather with blcak dots by $10-20 \%$ as Pucak SenSi-1 Agrinak chicken. Analysis results and the color of feather of SenSi-1 Agrinak chicken (Grey and Pucak) based on sex observed at 10 weeks old is presented in Figures 1-4.

Figure 1 shows that from 499 chickens observed, there are four feather colors of male Grey SenSi-1 Agrinak chickens: grey, black, golden brown and white with the percentage of $55.51 \% ; 20.64 \% ; 3.41 \%$ and $20.44 \%$ respectively. Meanwhile, from the 492 chickens observed in female Grey SenSi-1 Agrinak chicken, there are also four feather colors grey, black, golden brown and white with the percentage of $60.77 \%$; $15.24 \% ; 4.67 \%$ and $19.31 \%$ respectively.

The appearance of the four colors of feather in the Grey SenSi-1 Agrinak chicken is caused by certain pigments during their growth process. The pigments contained in the feather are lipoxrome and melanin (Natawiharja 2003). The golden old color of feather (s) is recessive to the silver color $(\mathrm{S})$, plain feather $(\mathrm{b})$ is recessive to the patterned feather $(\mathrm{B})$. The $\mathrm{S}$ and $\mathrm{s}$ genes are adrift on the sex chromosome, as well as the B and b gens (Hutt 1949). 
Male Pucak SenSi-1 Agrinak Chicken

24.35

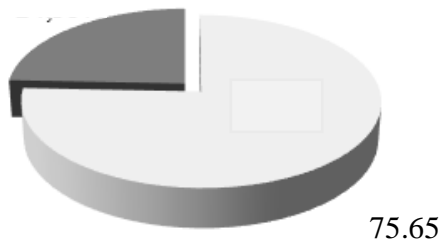

Female Pucak SenSi-1 Agrinak Chicken

16.30 0.40

White

- Grey

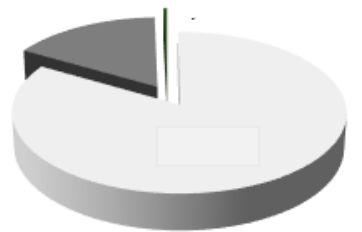

White

- Grey

- Brown

83.30

Figure 3. Color distribution of feather of male and female Pucak SenSi-1 Agrinak chicken (\%).
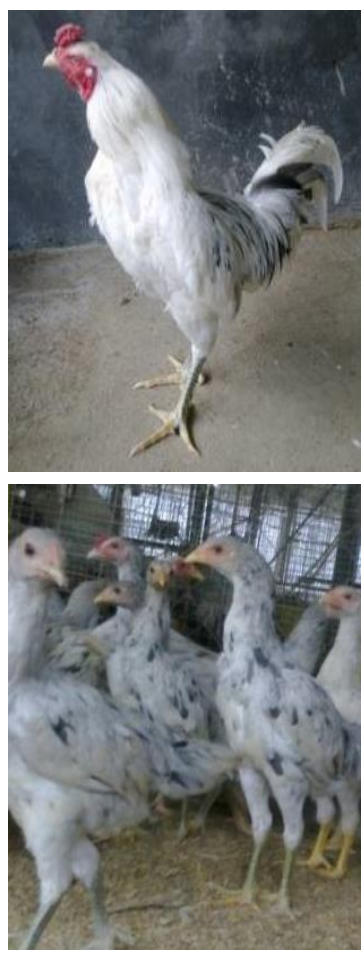
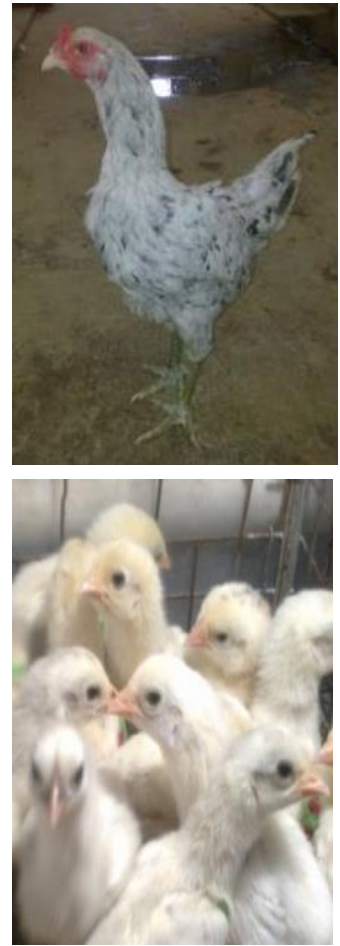

Figure 4. Pucak SenSi-1 Agrinak Chicken.

\section{Color of shank}

Observation of the shank color was also performed at the 10 weeks old. Observation results of the color shank of the Grey and Pucak SenSi-1 Agrinak chicken based on sex are presented in Figure 5 and Figure 6.

Figure 5 shows that shank color from 499 male Grey SenSi-1 Agrinak chickens is yellow, black, green, grey, white and brown with the percentage of $52.51 \%$; $24.05 \% ; 9.42 \% ; 15.14 \% ; 7.24 \%$; and $2.20 \%$ respectively. The shank color of 492 female grey SenSi1 Agrinak chicken is yellow: $33.33 \%$, black: $33.33 \%$, grey: $17.89 \%$, green: $12.60 \%$ and white: $2.85 \%$.
Figure 6 shows that shank color of 497 male Pucak SenSi-1 Agrinak is yellow: 51.91\%, green: $24.14 \%$, grey: $15.14 \%$, white: $7.24 \%$ and black: $0.20 \%$. Then, from 492 female Pucak SenSi-1 Agrinak chickens, there are five shank colors: yellow: $36.79 \%$, green: $39.02 \%$, grey: $18.29 \%$, white: $5.49 \%$, and black: $0.41 \%$.

The distribution of shank color of Grey and Pucak SenSi-1 Agrinak chickens both in the male and female was still varied (yellow, grey, black, green, brown and white). The large variation of shank color of the Grey and Pucak SenSi-1 Agrinak chicken has the great similarities with the most shank of the native chickens.

As the percentage of shank color distribution showedthat the yellow color was dominant. Yellow 
shank in the American chicken and other breed is formed by fat or lipoxrom pigment in the epididymis layer and no melanin pigment in the epididymis and dermis layers. Melanin gen in the dermis layer is recessive (id) to the melanin pigmentation inhibitor gen, lipoxcrom (Id). The existence of the gen B in chicken may decrease the number of melanin pigment in the shank.

The yellow color of the shank of female chicken may be used to estimate egg production rate by looking at color change of shank. The lipoxcrop pigment in the shank is identical with the yellow pigment in the egg. So that, the shank color may be used as an indication of egg production rate of a chicken. Therefore, the shank color change may be used for layer chicken culling (Jull 1951).

The meat color of the Grey and Pucak SenSi-2 Agrinak chicken was dominant light. Skin meat color is closely related to the meat color. The light color of the Grey and Pucak SenSi-1 Agrinak chicken meat is $\mathrm{m}^{-11} \mathrm{v}$ preferred bv the consumer.
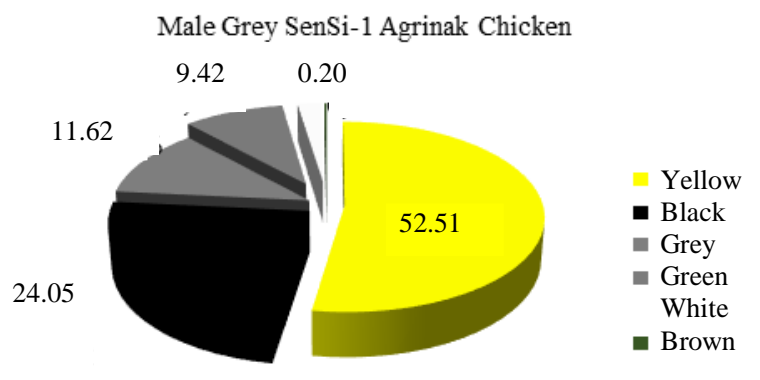

\section{Comb type}

The type of comb also becomes one unique characteristic of the SenSi-1 Agrinak chicken as the male line of native broiler chicken. The comb type of the SenSi-1 Agrinak chicken is a dominant pea. The Figure 7 and 8 shows the comb type of the SenSi-1 Agrinak chicken in this study.

Figure 7 shows the variance of the comb type of male Grey SenSi-1 Agrinak chicken $90.98 \%$ of pea and $9.02 \%$ of scomb. Whereas, in the female grey SenSi-1 Agrinak chicken, the pea type is $89.23 \%$, and the scomb type is $10.77 \%$. Figure 8 shows the dominant comb type of male Pucak SenSi-1 Agrinak chicken is the pea type of $91.55 \%$ with the recessive one is scomb of $8.45 \%$. Whereas, the dominant comb type of the female Pucak SenSi-1 Agrinak chicken is the pea type as well of $92.28 \%$, and $7.72 \%$ is the scomb type as the recessive

Figure 5. Color distribution of shank of male and female Grey SenSi-1 Agrinak chicken (\%).
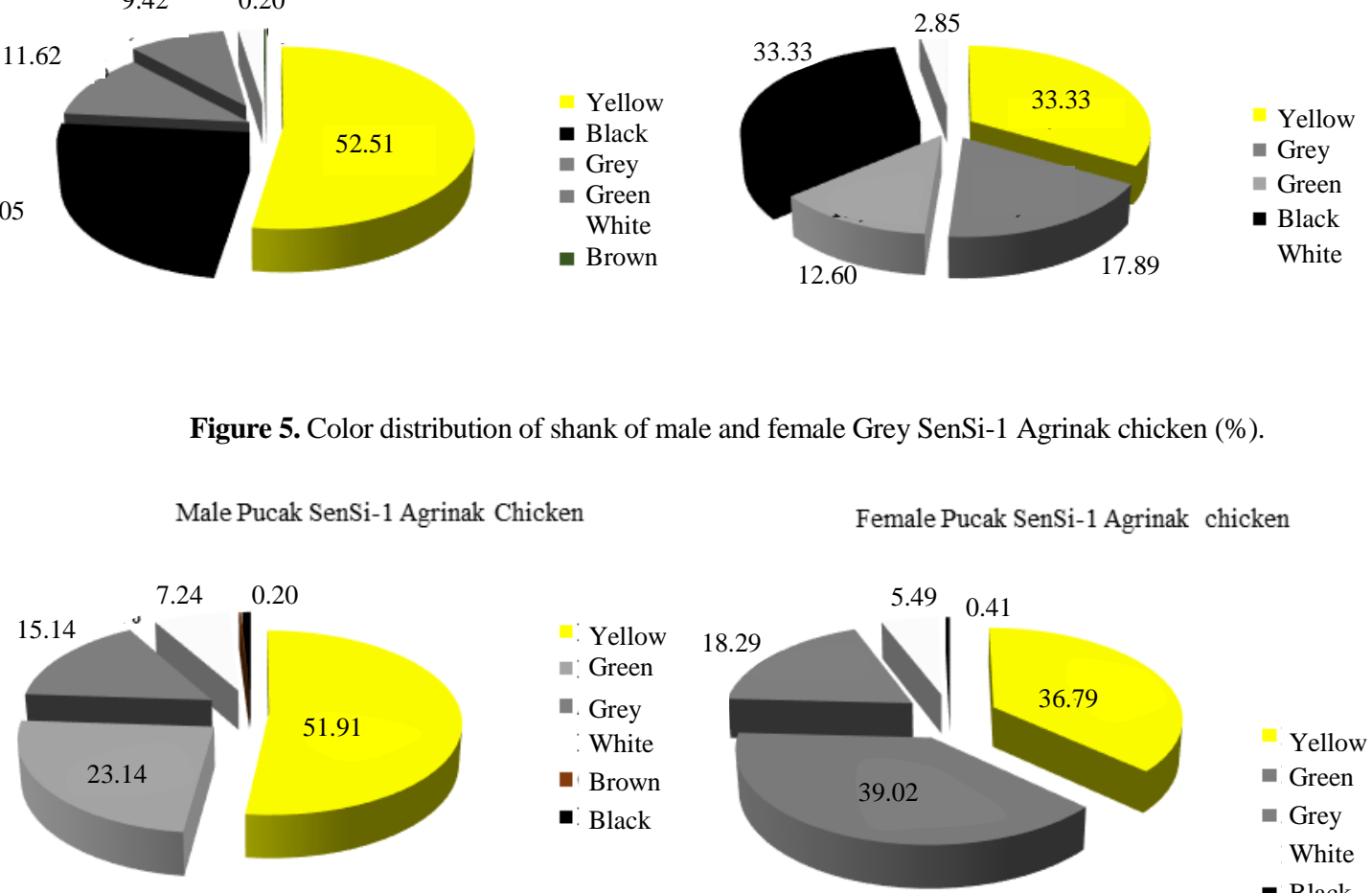

Figure 6. Color distribution of shank of male and female Pucak SenSi-1 Agrinak chicken (\%). 
Male Grey SenSi-1 Agrinak Chicen

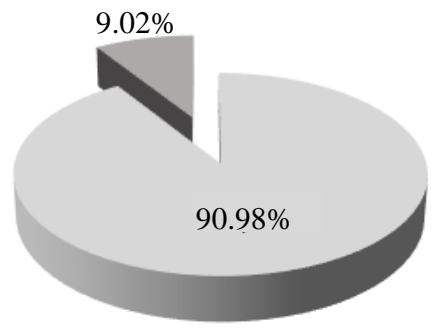

Female Grey SenSi-1 Agrinak Chicken

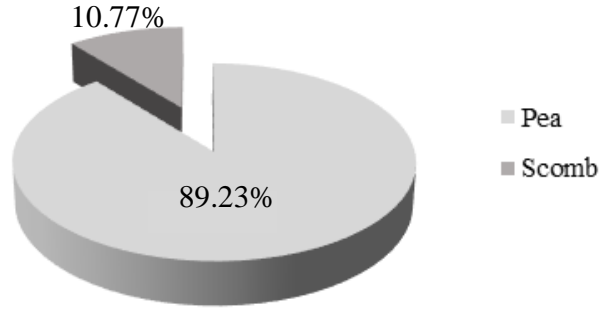

Figure 7. Distribution of comb type of the male and female Grey Sensi-1Agrinak chicken.

Male Pucak Sensi-1 Agrinak Chicken

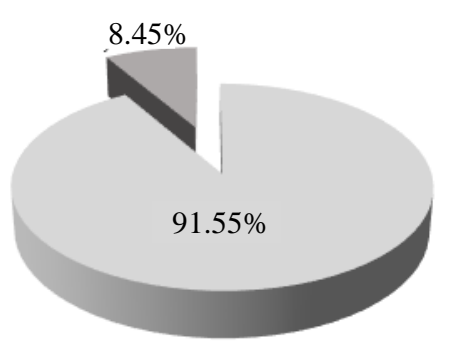

Female Pucak Sensi-1 Agrinak Chicken

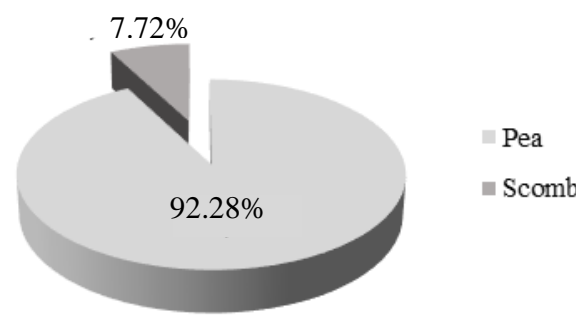

Figure 8. Distribution of comb type of the male and female Pucak Sensi-1Agrinak chicke

n

\section{Quantitative characteristics}

\section{Body weight at 0-9 weeks old}

Average live weight at $0-9$ weeks old is presented in Table 1, and based on the sex in Table 2.

The live weight observation was conducted for $10 \%$ of total population. Table 1 shows a normal growth performance indicated by the increase of live weight along with the age. The average live weight of Pucak SenSi-1 Agrinak chicken was higher of $745.66 \pm 68.75$ $\mathrm{g} /$ head than the Grey SenSi-1 Agrinak chicken of $731.57 \pm 75.61 \mathrm{~g} /$ head.

High value of the coefficient of variance of the Grey SenSi-1 Agrinak chicken indicating the absence of uniformity on the growth in the population. Different from Grey SenSi-1 Agrinak chicken, the coefficient of variance value of Pucak Sensi-1 Agrinak (fewer than
$15 \%$ ) shows that uniformity on the growth of the male and female SenSi-1 Agrinak chicken appeared at 10 weeks old is uniform. Nasoetion (1992) said that uniform livestock animal population has coefficient of variance value of $5-15 \%$. Then, Sidadolog (2011) suggested that common coefficient variance of native chicken is $25 \%$. The body weight of Grey and Pucak SenSi-1 Agrinak chicken as the male line at the $6^{\text {th }}$ generation is presented in Table 3 .

Table 3 shows that the average live weight of selected male at 10 weeks old based on feather color variance was $>1 \mathrm{~kg}$. The average live weight of Pucak SenSi-1 Agrinak was $1051 \pm 107 \mathrm{~g} /$ head from 103 head chicken, while the average live weight of Grey SenSi-1 Agrinak chicken was $1015 \pm 76 \mathrm{~g} / \mathrm{head}$ from the same number population with a coefficient of a variant of $7.22 \%-10.58 \%$. 
Table 1. Live weight of Grey and Pucak SenSi-1 Agrinak chicken at 0-9 weeks old

\begin{tabular}{|c|c|c|c|c|c|c|c|c|c|c|}
\hline \multirow{2}{*}{ Variable } & \multicolumn{10}{|c|}{ Age (week) } \\
\hline & 0 & 1 & 2 & 3 & 4 & 5 & 6 & 7 & 8 & 9 \\
\hline \multicolumn{11}{|c|}{ Live Weight of Grey SenSi-1 Agrinak } \\
\hline Average $(\mathrm{g} / \mathrm{head})$ & 29.72 & 51.42 & 86.38 & 128.79 & 182.14 & 266.66 & 366.52 & 467.40 & 612.27 & 731.57 \\
\hline $\begin{array}{l}\text { Standard of Deviation } \\
\text { (g/head) }\end{array}$ & 2.97 & 9.18 & 22.71 & 15.78 & 20.87 & 46.15 & 44.51 & 57.06 & 58.38 & 75.61 \\
\hline Coefficient of Variance (\%) & 9.98 & 17.85 & 26.29 & 12.26 & 11.46 & 17.31 & 12.14 & 12.21 & 9.54 & 10.34 \\
\hline Minimum (g/head) & 38.00 & 31.20 & 59.17 & 96.50 & 149.70 & 96.20 & 279.10 & 367.20 & 521.40 & 593.09 \\
\hline Maximum (g/head) & 23.00 & 64.00 & 171.40 & 146.30 & 221.60 & 327.90 & 489.10 & 591.60 & 738.30 & 889.30 \\
\hline \multicolumn{11}{|c|}{ Live Weight of Pucak SenSi-1 Agrinak } \\
\hline Average $(\mathrm{g} / \mathrm{head})$ & 30,49 & 51.04 & 60.69 & 118.46 & 178.43 & 258.87 & 368.12 & 459.11 & 607.53 & 745.66 \\
\hline $\begin{array}{l}\text { Standard of Deviation } \\
\text { (g/head) }\end{array}$ & 3,15 & 8.68 & 12.79 & 9.76 & 27.95 & 37.55 & 47.34 & 65.47 & 50.41 & 68.75 \\
\hline Coefficient of Variance (\%) & 10,33 & 17,00 & 21.07 & 8.24 & 15.66 & 14.51 & 12.86 & 14.26 & 8.30 & 9.22 \\
\hline Minimum (g/head) & 39,00 & 38,63 & 46.50 & 98.50 & 125.10 & 192.20 & 301.22 & 342.80 & 523.00 & 653.10 \\
\hline Maximum (g/head) & 22,00 & 67,00 & 87.80 & 130.30 & 229.90 & 327.22 & 473.30 & 587.20 & 728.10 & 933.10 \\
\hline
\end{tabular}

Table 2. Live weight of Grey and Pucak SenSi-1 Agrinak chicken at 10 weeks old

\begin{tabular}{|c|c|c|}
\hline Variable & Male & Female \\
\hline \multicolumn{3}{|l|}{ Grey SenSi-1 Agrinak Chicken } \\
\hline Population, (head) & 499 & 492 \\
\hline \multicolumn{3}{|l|}{ Live Weight } \\
\hline Average (g/head) & 886.38 & 739.17 \\
\hline Standard of Deviation, (g/ head) & 142.93 & 118.81 \\
\hline Coefficient of Variance (\%) & 16.12 & 16.07 \\
\hline Minimum (g/ head) & 323.00 & 339.00 \\
\hline Maximum (g/ head) & 1330.00 & 1075.00 \\
\hline \multicolumn{3}{|l|}{ Pucak SenSi-1 Agrinak Chicken } \\
\hline Population (head) & 497 & 492 \\
\hline \multicolumn{3}{|l|}{ Live Weight } \\
\hline Average, (g/ head) & 908.76 & 750.53 \\
\hline Standard of Deviation, (g/ head) & 130.98 & 110.56 \\
\hline Coefficient of Variance, $(\%)$ & 14.41 & 14.73 \\
\hline Minimum, (g/ head) & 515.00 & 323.00 \\
\hline Maximum, (g/ head) & 1251.00 & 1088.00 \\
\hline
\end{tabular}

\section{Feed consumption}

Feed consumption of Grey and Pucak SenSi-1 Agrinak chicken in Table 4 shows normal consumption increasing with increasing age and body weight. Both factors are closely related and interact with each other. The potential of high growth performance leads to high consumption of diet (in the ad libitum administration). 
As consequence, the body weight will highly be influenced by feed consumption. Until 10 weeks old, the Grey and Pucak SenSi-1 Agrinak chickens consumed similar diet by $70.99 \mathrm{gr} / \mathrm{head}$ and 78.31 $\mathrm{g} /$ head respectively. Cumulatively, the average amount of diet consumed until 10 weeks old of Grey and Pucak SenSi-1 Agrinak chicken was $\pm 2.5 \mathrm{~kg} / \mathrm{head}$.

\section{Carcass}

The carcass is a crucial factor in assessing meat production as an edible body part (Moran 1977). The carcass of the broiler chicken is part of live broiler chicken after slaughtered, and removal of the feather, viscera, abdominal fat, head, neck and the both legs. Table 5 shows carcass quality of Grey and Pucak SenSi-1 Agrinak chickens.

Average carcass weight of the Grey and Pucak SenSi-1 Agrinak both male and female was quite high by $75 \%$. This percentage is higher than the carcass percentage of crossed KUB with Sentul and Gaok chickens by $64.10-66.73 \%$ (Hasnelly 2013). Hasnelly (2013) stated that carcass production may be determined from cutting weight. The heavier cutting weight produces higher carcass. The common color of carcass of Grey and Pucak SenSi-1 Agrinak is yellowish white, besides gray carcass, especially of the grey SenSi-1 Agrinak chicken

Table 3. Live weight of selected male SenSi-1 Agrinak chicken at 10 weeks old

\begin{tabular}{lcc}
\hline \hline Variables & Grey SenSi-1 Agrinak & Pucak SenSi-1 Agrinak \\
\hline Population, (head) & 103 & 103 \\
Live Weight & & 1051 \\
Average (g/head) & 1015 & 76 \\
Standard of Deviation (g/ head) & 107 & 7.22 \\
Coefficient of Variance (\%) & 10.58 & 1251 \\
Minimum (g/ head) & 1330 & 903 \\
Maximum (g/head) & 839 & \\
\hline
\end{tabular}

Table 4. Feed consumption of Grey and Pucak SenSi-1 Agrinak at 0-10 weeks old

\begin{tabular}{|c|c|c|c|c|c|c|c|c|c|c|}
\hline \multirow{2}{*}{ Variables } & \multicolumn{10}{|c|}{ Age (week) } \\
\hline & 1 & 2 & 3 & 4 & 5 & 6 & 7 & 8 & 9 & 10 \\
\hline \multicolumn{11}{|c|}{ Feed consumption of Grey SenSi-1 Agrinak } \\
\hline Average (g/head) & 6.65 & 11.09 & 17.30 & 22.48 & 26.89 & 37.69 & 62.49 & 59.87 & 67.30 & 70.99 \\
\hline $\begin{array}{l}\text { Standard of Deviation } \\
(\mathrm{g} / \text { head })\end{array}$ & 0.95 & 1.32 & 1.95 & 6.98 & 6.79 & 4.22 & 14.51 & 12.53 & 15.38 & 21.16 \\
\hline Coefficient of Variance $(\%)$ & 14.22 & 11.91 & 11.26 & 31.05 & 25.27 & 11.19 & 23.23 & 20.93 & 22.85 & 29.81 \\
\hline Minimum (g/ head) & 5.24 & 9.16 & 15.01 & 18.78 & 20.03 & 3194 & 40.16 & 42.55 & 51.26 & 51.01 \\
\hline Maximum (g/ head) & 11.90 & 13.83 & 27.74 & 68.77 & 45.52 & 46.87 & 98.78 & 99.71 & 112.20 & 118.43 \\
\hline \multicolumn{11}{|c|}{ Feed consumption of Pucak SenSi-1 Agrinak } \\
\hline Average (g/head) & 6.93 & 11.38 & 17.79 & 21.49 & 29.63 & 41.12 & 60.88 & 66.09 & 70.79 & 78.31 \\
\hline $\begin{array}{l}\text { Standard of Deviation } \\
(\mathrm{g} / \text { head })\end{array}$ & 0.39 & 1.72 & 2.16 & 6.75 & 8.31 & 8.53 & 17.41 & 13.77 & 19.28 & 17.28 \\
\hline Coefficient of Variance $(\%)$ & 5.62 & 15.08 & 12.13 & 31.43 & 28.06 & 20.73 & 28.60 & 20.83 & 27.24 & 22.07 \\
\hline Minimum (g/ head) & 5.89 & 9.37 & 15.33 & 18.21 & 19.19 & 31.40 & 37.29 & 51.97 & 55.63 & 51.01 \\
\hline Maximum (g/ head) & 8.24 & 15.20 & 26.07 & 67.50 & 48.55 & 71.29 & 111.52 & 103.41 & 112.68 & 106.65 \\
\hline
\end{tabular}


Table 5. Carcass and carcass pieces of SenSi-1 Agrinak chicken at 10 weeks old

\begin{tabular}{|c|c|c|c|c|c|c|c|c|}
\hline \multirow{2}{*}{ Breed } & \multirow{2}{*}{$\begin{array}{c}\text { Live } \\
\text { Weight } \\
\text { (g/head) }\end{array}$} & \multicolumn{2}{|c|}{ Whole Carcass } & \multirow{2}{*}{$\begin{array}{l}\text { Liver } \\
\text { (g/head) }\end{array}$} & \multirow{2}{*}{$\begin{array}{l}\text { Rempela } \\
\text { (g/head) }\end{array}$} & \multirow{2}{*}{$\begin{array}{c}\text { Both } \\
\text { Legs } \\
\text { (g/head) }\end{array}$} & \multirow{2}{*}{$\begin{array}{c}\text { Head } \\
(\mathrm{g} / \mathrm{head})\end{array}$} & \multirow{2}{*}{$\begin{array}{c}\text { Abdominal } \\
\text { Fat } \\
\text { (g/head) }\end{array}$} \\
\hline & & (g/head) & $(\%)$ & & & & & \\
\hline \multicolumn{9}{|c|}{ Male Grey SenSi-1 Agrinak Chicken } \\
\hline Average (g/head) & 969.50 & 699.30 & 7865 & 23.10 & 27.40 & 49.00 & 89.70 & 4.40 \\
\hline $\begin{array}{l}\text { Standard of Deviation } \\
(\mathrm{g} / \text { head })\end{array}$ & 103.15 & 76.38 & 0.79 & 4.07 & 6.65 & 6.31 & 8.22 & 2.63 \\
\hline Coefficient of Variance (\%) & 10.64 & 10.92 & 1.00 & 17.61 & 24.28 & 12.87 & 9.16 & 59.84 \\
\hline Minimum (g/ head) & 813.00 & 579.00 & 76.86 & 17.00 & 20.00 & 39.00 & 80.00 & 1.00 \\
\hline Maximum (g/ head) & 1129.00 & 809.00 & 79.47 & 30.00 & 40.00 & 57.00 & 104.00 & 9.00 \\
\hline \multicolumn{9}{|c|}{ Female Grey SenSi-1 Agrinak Chicken } \\
\hline Average (g/head) & 794.80 & 537.20 & 76.94 & 22.60 & 26.80 & 40.30 & 71.10 & 4.70 \\
\hline $\begin{array}{l}\text { Standard of Deviation } \\
\text { (g/ head) }\end{array}$ & 73.66 & 43.38 & 1.89 & 3.06 & 5.43 & 4.90 & 9.90 & 4.32 \\
\hline Coefficient of Variance (\%) & 9.27 & 8.08 & 2.46 & 13.55 & 20.27 & 12.16 & 13.93 & 91.95 \\
\hline Minimum (g/ head) & 668.00 & 447.00 & 73.98 & 17.00 & 19.00 & 31.00 & 59.00 & 1.00 \\
\hline Maximum (g/ head) & 898.00 & 607.00 & 79.89 & 26.00 & 38.00 & 46.00 & 94.00 & 12.00 \\
\hline \multicolumn{9}{|c|}{ Male Pucak SenSi-1 Agrinak Chicken } \\
\hline Average (g/head) & 971.10 & 686.40 & 78.65 & 23.60 & 27.00 & 49.10 & 83.60 & 2.80 \\
\hline $\begin{array}{l}\text { Standard of Deviation } \\
(\mathrm{g} / \text { head })\end{array}$ & 91.43 & 80.55 & 1.83 & 2.37 & 3.50 & 8.95 & 13.47 & 2.66 \\
\hline Coefficient of Variance (\%) & 9.42 & 11.73 & 2.33 & 10.03 & 12.95 & 18.23 & 16.11 & 94.94 \\
\hline Minimum (g/ head) & 843.00 & 568.00 & 76.24 & 18.00 & 21.00 & 31.00 & 51.00 & 1.00 \\
\hline Maximum (g/ head) & 1111.00 & 831.00 & 82.36 & 26.00 & 34.00 & 59.00 & 95.00 & 9.00 \\
\hline \multicolumn{9}{|c|}{ Female Pucak SenSi-1 Agrinak Chicken } \\
\hline Average, (g/head) & 786.20 & 561.70 & 78.35 & 19.60 & 24.20 & 38.30 & 70.70 & 2.22 \\
\hline $\begin{array}{l}\text { Standard of Deviation, (g/ } \\
\text { head) }\end{array}$ & 108.29 & 76.81 & 1.20 & 2.55 & 3.77 & 5.96 & 9.86 & 1.86 \\
\hline Coefficient of Variance (\%) & 13.77 & 13.67 & 1.54 & 13.00 & 15.56 & 15.57 & 13.94 & 83.52 \\
\hline Minimum (g/ head) & 602.00 & 427.00 & 76.62 & 16.00 & 17.00 & 32.00 & 56.00 & 1.00 \\
\hline Maximum (g/ head) & 954.00 & 678.00 & 80.85 & 24.00 & 29.00 & 49.00 & 88.00 & 8.00 \\
\hline
\end{tabular}


Table 6. Body weight and size of adult Grey and Pucak SenSi-1 Agrinak chicken

\begin{tabular}{|c|c|c|c|c|c|c|c|c|c|c|}
\hline \multirow{2}{*}{ Variable } & \multicolumn{5}{|c|}{$\begin{array}{c}\text { Male } \\
(\mathrm{N}=25 \text { head })\end{array}$} & \multicolumn{5}{|c|}{$\begin{array}{c}\text { Female } \\
(\mathrm{N}=25 \text { head })\end{array}$} \\
\hline & Maxim & Minim & Average & StDev & $\begin{array}{c}\text { CoVar } \\
(\%)\end{array}$ & Maxim & Minim & Average & StDev & $\begin{array}{c}\text { CoVar } \\
(\%)\end{array}$ \\
\hline \multicolumn{11}{|c|}{ Grey SenSi-1 Agrinak Chicken } \\
\hline Live weight (g) & 3706.00 & 2466.00 & 3050.17 & 323.21 & 10.60 & 2623.00 & 1560.00 & 2032.48 & 252.34 & 12.42 \\
\hline Beak length $(\mathrm{cm})$ & 37.34 & 16.41 & 28.01 & 5.22 & 18.62 & 34.89 & 21.01 & 30.78 & 3.76 & 12.23 \\
\hline Beak width $(\mathrm{cm})$ & 15.76 & 9.36 & 12.82 & 1.86 & 14.55 & 19.51 & 10.89 & 16.23 & 3.01 & 18.54 \\
\hline Head length $(\mathrm{cm})$ & 57.45 & 36.23 & 48.26 & 5.43 & 11.25 & 51.87 & 34.63 & 45.28 & 3.86 & 8.53 \\
\hline Head width $(\mathrm{cm})$ & 39.52 & 24.92 & 32.91 & 3.01 & 9.14 & 34.09 & 27.56 & 31.64 & 1.38 & 4.35 \\
\hline Neck length $(\mathrm{cm})$ & 18.00 & 13.00 & 16.04 & 1.49 & 9.26 & 13.50 & 11.00 & 12.50 & 0.60 & 4.76 \\
\hline Back length $(\mathrm{cm})$ & 35.00 & 21.00 & 24.19 & 2.90 & 11.98 & 25.00 & 21.00 & 22.58 & 1.04 & 4.60 \\
\hline Chest circumference $(\mathrm{cm})$ & 43.00 & 33.00 & 38.92 & 2.63 & 6.75 & 36.00 & 28.50 & 32.20 & 1.69 & 5.25 \\
\hline Chest length $(\mathrm{cm})$ & 19.00 & 13.00 & 14.76 & 1.51 & 10.22 & 19.00 & 16.00 & 17.78 & 0.87 & 4.88 \\
\hline Upper thighs length $(\mathrm{cm})$ & 14.00 & 11.00 & 12.56 & 0.96 & 7.65 & 12.00 & 8.00 & 10.24 & 0.83 & 8.11 \\
\hline Lower thighs length $(\mathrm{cm})$ & 17.00 & 13.00 & 14.34 & 1.21 & 8.46 & 13.00 & 11.00 & 12.08 & 0.62 & 5.16 \\
\hline Shank length $(\mathrm{cm})$ & 14.00 & 9.00 & 10.68 & 1.03 & 9.64 & 9.00 & 7.00 & 7.94 & 0.55 & 6.88 \\
\hline \multicolumn{11}{|c|}{ Pucak SenSi-1 Agrinak Chicken } \\
\hline Live weight (g) & 3808.00 & 2764.00 & 3190.80 & 219.53 & 6.88 & 2631.00 & 1538.00 & 2200.04 & 254.80 & 11.58 \\
\hline Beak length $(\mathrm{cm})$ & 42.35 & 30.84 & 36.97 & 2.76 & 7.47 & 35.52 & 23.46 & 29.27 & 3.00 & 10.27 \\
\hline Beak width $(\mathrm{cm})$ & 20.54 & 13.77 & 17.55 & 1.56 & 8.88 & 14.76 & 10.07 & 11.72 & 1.25 & 10.64 \\
\hline Head length $(\mathrm{cm})$ & 58.21 & 46.26 & 51.72 & 2.98 & 5.76 & 45.91 & 31.07 & 40.44 & 3.90 & 9.65 \\
\hline Head width $(\mathrm{cm})$ & 41.39 & 32.67 & 36.21 & 2.35 & 6.49 & 33.44 & 23.08 & 28.11 & 2.10 & 7.48 \\
\hline Neck length, $(\mathrm{cm})$ & 17.50 & 14.00 & 15.58 & 0.96 & 6.19 & 14.00 & 11.00 & 12.92 & 0.86 & 6.67 \\
\hline Back length $(\mathrm{cm})$ & 29.50 & 25.00 & 26.94 & 1.38 & 5.12 & 23.00 & 16.00 & 19.88 & 1.94 & 9.78 \\
\hline Chest circumference $(\mathrm{cm})$ & 41.00 & 35.00 & 37.12 & 1.58 & 4.26 & 37.00 & 28.00 & 33.92 & 2.08 & 6.13 \\
\hline Chest length $(\mathrm{cm})$ & 27.00 & 20.00 & 22.66 & 1.50 & 6.61 & 17.00 & 12.00 & 15.32 & 1.35 & 8.78 \\
\hline Upper thighs length $(\mathrm{cm})$ & 14.00 & 12.00 & 12.80 & 0.61 & 4.78 & 14.00 & 10.00 & 11.08 & 0.76 & 6.85 \\
\hline Lower thighs length $(\mathrm{cm})$ & 17.50 & 14.00 & 15.28 & 0.87 & 5.67 & 14.00 & 11.00 & 12.48 & 0.77 & 6.17 \\
\hline Shank length (cm) & 15.00 & 9.50 & 10.88 & 1.08 & 9.95 & 9.00 & 7.00 & 7.96 & 0.35 & 4.41 \\
\hline
\end{tabular}

\section{Body size}

Body size observation was conducted at 12 months of age (adult) as a consideration that there is no change in body size of the adult. The body size also describes the uniqueness of the SenSi-1 Agrinak chicken as male line of native broiler chicken. Table 6 presents adult body weight and body size of Grey and Pucak SenSi-1 Agrinak chickens both the male and female.
Average live weight of the adult Grey and Pucak SenSi-1 Agrinak chickens of $3.050 \mathrm{~kg} / \mathrm{head}$ and $3190.80 \mathrm{~g} / \mathrm{head}$ respectively was higher than body weight of adult Sentul chicken of $2.24 \mathrm{~kg}$ (Munggaran 2004), and higher than another native chickens such as Arab chicken of $2.04 \mathrm{~kg}$ (Rukmana 2003), and Merawang chicken of $2.36 \mathrm{~kg}$ (Hasnelly et al. 2006). The supposition of live weight increase is a selection response showed in the male Grey SenSi-1 Agrinak chicken of $25.55 \mathrm{~g} / \mathrm{head} /$ generation or 37.41 
$\mathrm{g} /$ head/generation and in the Pucak SenSi-1 Agrinak chicken of $30.23 \mathrm{~g} / \mathrm{head} /$ generation, or 40.94 $\mathrm{g} /$ head/generation. However, the actual and real selection response was higher by 43.50 $\mathrm{g} /$ head/generation or $55.33 \mathrm{~g} /$ head/generation and 38.50 $\mathrm{g} /$ head/generation or $47.67 \mathrm{~g} /$ head/generation (Iskandar et al. 2015)

Body size of adult Grey and Pucak SenSi-1 Agrinak chicken may become unique characteristics of SenSi-1 Agrinak chicken. The body firm may also vary as an influence of the quality and quantity of the diet. In reverse, the length of neck, legs and chest is not affected by the quality and quantity of diet. The abnormal body shape of the adult chicken may appear due to malnutrition during its growth (Iskandar et al. 2016). Therefore, the body size of Sentul chicken presented was normal body size. When the body appearance is combined with the feather color, the unique Sentul chicken will be appeared. The body size, in many ways, is specific. This size will form a unique stereotype of the Sentul chicken. Starting from the shape of head, the shape of body and leg, harmoniously will deliver a specific impression (Sartika et al. 2007). Change of body weight shows body development of the young chicken, while the change of body size shows the growth and development of body parts (Sasimowski 1987). The average bone development increases at 4-12 weeks of age and decreases at 12-20 weeks of age. There are only a few changes of bone in the adult bird, so the measurement of bone to determine body size at the adult age gives the more accurate results (Hutt, 1949). Therefore, the body size may be used to observe quantitative characteristics of chicken.

\section{CONCLUSION}

Grey SenSi-1 Agrinak chicken had dark to light grey color of feather, while the Pucak SenSi-1 Agrinak chicken had white feather with black dots by $10-20 \%$. The SenSi-1 Agrinak chicken also had dominant pea comb type and dominant yellow shank. The body weight of selected male SenSi-1 Agrinak chicken at 10 weeks might reach 1.015-1.051 kg/head. The body weight and size of adult male and female SenSi-1 Agrinak chickens was uniform with average coefficient of variance was lower than $15 \%$.

\section{REFERENCES}

Agriflo. 2013. Ayam kampung. Cimanggis (Depok): Penerbit Penebar Swadaya,

Han J. 2014. Origin and evolution of molecular diversity of indigenous animal genetic resources. Proceedign AAAP 16 th: Yogyakarta, Indonesia.
Hardjosubroto W. 2002. Aplikasi pemuliaan ternak di lapangan. Jakarta (Indones): Grasindo.

Hasnelly Z. 2013. Karakteristik karkas dan preferensi konsumen terhadap daging ayam lokal hasil persilangan. Seminar Nasional Kemandirian Pangan. UNPAD, Jatinangor

Hasnelly Z, Lia S, Ulfha. 2006. Performans ayam Merawang jantan dewasa berdasarkan karakter kualitatif dan ukuran tubuh sebagai bibit. Prosiding Seminar Nasional PATPI. Yogyakarta (Indones).

Henuk YL, Bailey CA. 2014. Husbandry systems for native chickens in Indonesia. Proceedings of The 16th AAAP Animal Science Congress. Yogyakarta (Indones): University of Gadjah Mada. p. 759-762.

Hutt FB. 1949. Genetics of the Fowl. New York (USA): McGraw-Hill Book Campany Inc.

Jull MA. 1951. Poultry husbandry, 3nd ed. New York (USA): McGraw-Hill Book Inc. p. 34-35.

Iskandar S, Sartika T. 2015. Selection for 10 weeks old bodyweight on Sentul chicken. Proceedings of the 6th ISTAP, International Seminar on Topical Animal Production. Yogyakarta (Indones): Faculty of Animal Science, Universitas Gadjah Mada. p. 387-390.

Iskandar S, Sartika T, Hasnelly Z, Gunawan B. 2016. Naskah ilmiah pelepasan galur ayam lokal pedaging Sensi abu dan Sensi putih. Bogor (Indones): Balai Penelitian Ternak.

Kusuma AS. 2002. Karakteristik sifat kuantitatif dan kualitatif ayam Merawang dan ayam Kampung umur 5-12 Minggu. Skripsi Fakultas Peternakan IPB, Bogor. 1719.

Mansjoer SS.1981. Studi sifat-sifat ekonomis yang menurun pada ayam kampung. Laporan Penelitian No 15/ Penelitian/PUT/IPB/1979-1980. Bogor (Indones): Fakultas Peternakan. Institut Pertanian Bogor.

Moran ET. 1977. Growth and meat yield in poultry. In: Boorman KN, Wilson BJ, editors. Growth and Poultry Meat Production. Edinburgh (UK): British Poultry Science Ltd. p. 145-173.

Sartika T, Iskandar S. 2007. Mengenal plasma nutfah ayam indonesia dan pemanfaatannya. 1st ed. Bogor (Indones): Balai Penelitian Ternak.

Sasimowski. 1987. Animal breeding and production an outline. Warszawa (Switzerland): PWN-Publish Scientific Publishers.

Sidadolog JHP. 2011. Pemuliaan sebagai sarana pelestarian dan pengembangan ayam lokal. Pidato Pengukuhan Jabatan Guru Besar pada Fakultas Peternakan Universitas Gadjah Mada. Yogyakarta (Indones): Universitas Gadjah Mada.

Suprijatna E. 2005. Ayam buras krosing petelur. Jakarta (Indones): Penebar Swadaya. 
Sulandari S, Zein MSA, Paryanti S, Sartika T, Sidadolog JHP, Astuti M, Widjastuti T, Sujana E, Darana S, Setiawan I, Garnida D, Iskandar S, Zainuddin D, Herwati T, Wibawan IWT. 2007. Keanekaragaman sumber hayati ayam lokal Indonesia: Manfaat dan potensi. Bogor (Indones): Pusat Penelitian Biologi LIPI.

Munggaran, Deden K. 2004. Identifikasi sifat-sifat kuantitatif dan ukuran-ukuran tubuh pada ayam Sentul umur dewasa (Skripsi). [Bandung (Indones)]: Fakultas Peternakan, Universitas Padjadjaran.
Nasoetion AH. 1992. Panduan berfikir dan meneliti secara ilmiah bagi remaja. Jakarta (Indones): Gramedia.

Rukmana R. 2003. Ayam buras intensifikasi dan kiat pengembanganan. Yogyakarta (Indones): Kanisius. 